\title{
The Role of Public Relations in Creating Cordial Relationship with the Relevant Publics: A Study of A.B.U/MTN Library Connect
}

\author{
Ben Odeba ${ }^{1}$, and Jennifer I. Osazuwa ${ }^{2}$ \\ ${ }^{I}$ Directorate of Academic Planning, Bingham University, Karu, Nasarawa State, Nigeria \\ ${ }^{2}$ Directorate of Public Affairs, Bingham University, Karu, Nasarawa State, Nigeria
}

\begin{abstract}
In order to create and sustain a cordial relationship with Ahmadu Bello University (ABU) Community, MTN introduced a project called "MTN Library Connect" in the University. This paper, "The Role of Public Relations in Creating Cordial Relationship with the Relevant Publics: A Study of A.B.U./MTN Library Connect", examined the use of MTN Foundation Connect Library in institutions of higher learning in Nigeria. The purpose of the investigation is to determine whether or not MTN achieved a cordial relationship with Ahmadu Bello University Community which is one of the beneficiaries of the Project. Survey research design was adopted for the study with questionnaire as the instrument to elicit data from 120 respondents in twelve (12) Faculties of the University, comprising 100 from the Main campus, and 20 from Kongo campus. Findings reveal that, majority of the students appreciate the services rendered by the A.B.U./MTN Library Connect. Further findings indicate that the MTN Library Connect is effective as it helps the telecom company to carry out its corporate social responsibility by creating and maintaining cordial relationship as well as providing students with the necessary facilities which enable them to carry out their research. Findings also indicate that training of users on how to use the facility has been a major challenge. The study therefore recommends among others that the MTN Management should intensify efforts in creating more awareness about training students and extension of space to accommodate more students, provision of more systems and servers to cater for the ever-increasing number of students in the University.
\end{abstract}

Key Words: Public Relations, Cordial Relationship, Relevant Publics, A.B.U. Zaria, MTN Library Connect

\section{INTRODUCTION}

$\mathrm{P}$ bblic relations practice is a continuous effort to bring about harmonious adjustment between an organization and its various publics. Individuals engage in public relations activities daily with regards to the impression they create in the mind of others about themselves. According to the British Institute of public Relations, "public relations is the planned, deliberate and sustained effort to establish and maintain goodwill and mutual understanding between an organization and its publics". It is deliberate in the sense that, it is a conscious effort and, in most cases, the public relations executive or practitioner is fully aware that he/she is conducting or carrying out a public relations activity. This is carried out frequently in order to ensure lasting peace in an organization, and to prevent disaster from ever cropping up.
This is where the issue of sustenance comes in as public relations is not a one and-for-all activity. However, if the goodwill and mutual understanding an organization has been able to secure with its relevant publics is to be maintained, its public relations activities must be sustained. Public relations activities are sustained over time so as to create and maintain cordial relationship between the organization and its publics.

One may therefore agree with Brassington and Pettitt's (1997) position that, "the essence of public relations is to look after the nature and quality of the relationship between the organization and its various public" cited by Daramola (2003:236).

The acknowledgement of public relations as an accountable and result-oriented profession is fast gaining ground by the day due to its demanding and sophisticated jet-age. It is now embraced by every stratum of human endeavour, be it business, government, hospital, educational sectors, individuals, etc. public relations which is known to be the 'back bone' of any organization is fashioned to properly handle the communication business of such organization which is done by disseminating reliable information to the public about an organization, and to the organization about the public in order to create mutually beneficial co-existence.

Therefore, in considering the MTN foundation connect being a means through which MTN Nigeria implement her corporate social responsibility, the study looked into the major public relations activities carried out by MTN and how it has through the MTN foundation connect helped in creating cordial relationship with A.B.U public as the receiving institution.

The MTN Foundation connect which is a community service, was incorporated in July, 2004 serving as a vehicle through which MTN Nigeria implements her corporate social responsibility programmes. Sequel to its incorporation, MTN held consultations in September, 2004 with the stakeholders to determine the needs of the people, which include education, health, and economic empowerment.

MTN Foundation Universities Connect Project provides a link to the world's largest collection of digital resources from over 5,500 libraries and 300 publishers to assist university students and professors with research. Other bodies serving as 
beneficiaries from the valuable resources include government officials, media, industry experts, and researchers in other academic institutions. The Project which is managed by Net Library Nigeria, first took off at the University of Lagos (UNILAG) in December, 2005 following that of Ahmadu Bello University, Zaria in March, 2007 serving as the second beneficiary of the project. This was incorporated with a set of trained staff to help in hastening up the learning process of intended publics.

More so, the Universities connect (A.B.U) is equipped with one hundred and twenty-eight computers with interconnectivity and access to over 5,500 libraries worldwide and three hundred (300) published works. Students of the Ahmadu Bello University, Zaria, are the major beneficiaries of the MTN foundation connect, because each student is entitled to 120 minutes per day to browse the internet and other related journals.

A total sum of $\$ 10$ is charged for every page printed out ( 10 per page) compared to that charged in business centres ( $\$ 20)$. Furthermore, the Universities connect (A.B.U) operates from Mondays to Fridays within the hours of $9 \mathrm{am}$ to $7 \mathrm{pm}$ with two hours interval daily.

Other activities carried out by MTN foundation connect (A.B.U) includes creating awareness through workshops and seminars, which is done in order to get students, as well as staff acquainted with the use of the Net library. At the end of the workshop, certificates are awarded to participants. The awareness workshop is done yearly for every new student admitted.

However, the foundation operates based on an annual grant of $100 \%$ funding from MTN Nigeria, giving it up to $1 \%$ of its post-tax profits that covers all the foundations overhead expenses including: staffing, accommodation, travel, publicity, and all other expenses necessary to operate. The foundation is committed to partnering with international and local organization such as; NGO's private and public sectors as well as community-based organizations to deploy and execute programmes that are sustainable in the aforementioned key focus areas of the foundation.

The MTN foundation consist of board of directors, patrons, and executive secretary who run the activities of the foundation connect. Its mission is to bridge the knowledge and digital divide through information and communication technology education (ICT), to bring knowledge to the communities and open the minds of the youth of boundless opportunities.

Most business organization operating within Nigeria make so much profit and they give little or nothing back to the society. Also, most of them see engaging in corporate social responsibility activities as a waste of resources that will not bring any financial returns as such, they concentrate more on the product distribution and sales aspects of their business operation, neglecting the public relations aspect. This has resulted to image crises for most business organizations and as such has affected the perception of their product, service and policies by the public. (Ajala, 2001)

However, despite MTN Nigeria limited investing massively in corporate social responsibility through its MTN foundation connect library in institutions of higher learning in Nigeria, can we say it has achieved cordial relationship with A.B.U. Community which is one of the beneficiaries of the project? The problem necessitating this study therefore becomes even more evident when one considers the several complaints by the users such as poor networking, lapses in administrative coordination, inconsistency in system operation and inadequate coverage.

\section{Research Questions}

The following questions were set to guide the study:

How do students perceive the role of MTN connect in creating understanding between the organization and the students?

Does the MTN Foundation Connect Library render reliable services and is the A.B.U. Community, specifically students, aware of the project?

What are the A.B.U. publics perception of MTN Nigeria presently?

\section{LITERATURE REVIEW}

\section{Clarification of Concepts}

This section of the paper reviews the main concepts such as publics in public relations, role of public relations in image building, corporate social responsibility among others, are extensively reviewed.

\section{Public Relations}

Public relations encompass all areas of human endeavour. In the corporate world, educational sector and, entertainment industry, public relations is the force of attention. However, suffice it to say, the term, public relations, is so broad a concept, so diversified in outlook as several scholars has made an attempt in defining the concept (public relations), but an attempt to provide a satisfactory definition for it will, in most cases prove futile. This goes further to justify the statement put forward by Akande (1999:14) thus, "defining public relations is herculean task". In fact, public relations defies a single, all encompassing, comprehensive definition that touches all areas and aspects of the practice.

According to McElreath (1996), "public relations, is a management function that uses communication to facilitate relationships and understanding between an organization and its publics. In the words of Stanley (1982:25), "it is a management function that determines the attitude and opinion of the organizations public, and formulates and executes a programme of action to earn the understanding and goodwill of its publics". Despite the fact that both definitions centre the practice of public relation around corporate context (social responsibility of society), the above definition appears to be more elaborate and all-embracing than the previously 
mentioned one, as it centres only on corporate context which happens not to be the only essential ingredient of public relations. In the above definition, it could be seen that other elements were included such as goodwill and mutual understanding which inform us that, practitioners are aware that goodwill opens door of opportunities for an organization and provide a ready avenue for the sales of its goods, services, and ideas. By mutual understand, it means the public relation officer (PRO) is out to create rapport and friendly atmosphere between the organization and its publics.

Haywood (1984:20), says, "public relations is the projection of personality of an organization, it is the organized two-way communication between the organization and the audience critical to its success". Ajala (1993:12) corroborates this definition as put forward by Haywood by defining public relations as "establishing and maintaining two-way communication between the organization and its various publics in order to prevent misunderstanding and conflict". The main thesis, of these two definitions are; communication and image making. Communication of course, is central to and is, in fact the key thing in public relations, of which without, a public relations activity ceases to be. It is a two way thing and not one sided, which exists between an organization (sender), and its various publics (receiver).

However, the most charming, personable, friendly person in the world will be a complete failure if he cannot communicate. One of the legendary public relations consultant and author Nolte (1974), postulate that "there are two requirements for success in the field of public relations. First, the person must have an agreeable, likeable personality. Secondly, the person must be able to communicate" (Ajala 2003). Many organizations today, have failed in the area of communication by not communicating its activities properly to its publics, which has made its activities ending in an entirely fruitless venture. This has further posed misunderstanding and conflicts to the organization by its publics. Judging from this fact, comes the issue of image making, as a bad communication tend to lead to wrong or negative perception or impression of such organization by its publics. A good image built over the years can see a company through during its dark and bleak period, but a poor image on the other hand is a handicap which can take company years to overcome (Daramola, 2003).

Public relations as defined by Moss (1990), an experienced public relations scholar and instructor at the University of starling, Scotland consists wholly or as part of every manager's portfolio or responsibilities, a means of understanding and influencing the perception held by an organization, a strategic counseling function, a potentially valuable and cost effective making function, a means of monitoring and managing internal communications, an issue management function and an effective crisis management function.

In essence, what he says is that, public relations is "reputation management, reinforcing reputation, enhancing reputation and combating damage to reputation". This, obliviously summarizes all the above facts about public relations lettered “a $-\mathrm{g}$ " as presented by Danny Moss. The eyes and ears of management". In the same vain, Ajala (2001), further gives a more elaborate definition of public relations thus; "the totality of an organization or individual's performance aimed at earning public favorability which results in continued growth mutually beneficial to the organization (or individual) and the society within which it operates". (Ajala, 2001, Black, 1990).

Among the various definitions of public relations, the one which has gained so much credit is that, given by the British institute of public relations in the United Kingdom thus: "public relations is a planned, deliberate and sustained effort, to establish and maintain goodwill and mutual understanding between an organization and its publics" A review of the above definition shows that, public relations are planned, which implies that they are not done haphazardly. It entails a lot of brain work. And its tactful execution, which more often than not, guarantees its success, is contingent on the brain work and intelligence of the public relations practitioner, in the course of its execution.

Further to, it is the zeal to create goodwill and mutual understanding, as well as preventing disaster, which propels the PR executive to deliberately conduct the programme. If the goodwill and mutual understanding an organization has been able to maintain and secure with its relevant publics is to be maintained, its public relations activities must be sustained.

Today, the practice has gone beyond the elementary stage, due to its sophistication jet-age, which now occurs at many levels. One may therefore agree with Johnston and Zawawi's (2004) position that public relations "is the ethical and strategic management of communication and relationships in order to build and develop coalitions and policy, identify and manage issues and create and direct messages to achieve sound outcomes within socially responsible framework". Going by this definition which is much elaborate with regards to present $\mathrm{PR}$ practice, reveals $\mathrm{PR}$ as a process that can occur at all levels, and as well explains the way in which practitioners, whether in government, corporations or working for a community group, can use the same basic set of skills and techniques even though this may occur for widely different purpose.

Therefore, to all intents and purposes, public relations may be considered as the quality and nature of an organization relationship with various interested publics. These might include customers and suppliers, shareholders, trade union, the media, government and other regulatory bodies and pressure groups.

\section{Publics in Public Relations}

Every organization has its own specific publics to which it directs its policies or programmes, who are affected by the diverse activities of such organization either directly or indirectly. This public could as well be affected either positively or negatively. According to Moss (1990), in the 
context of public relations, a public is a group of people bound together by a common interest that is specific to them and their situation. Similarly, Jefkins (1992) sees publics "as those group of people, internally and externally, with whom an organization communicates".

Internally, it refers to publics within an organization, while externally on the other hand refers to publics such as; consumers stakeholders, community group, and other special interest group. Each of these publics are interested in a company as a source of benefit. This couple with the fact, of a public relations practitioner's sound knowledge, of all the relevant publics to its organization. As an ad that fails to identify and address its target audience is doomed to fail, so does a public relation executive who communicates to an irrelevant public.
This various but specific publics are very important to the existence and planning of an organization, and issues faced by these publics are different from that faced by publics of other organization. For instance, the issues faced by the target public of MTN Nigeria, are quite different from that faced by publics of other Telecommunication Industries; Glo, Airtel, Starcom and the likes. More so, all these organizations have their strategic means of meeting up with the needs of their specific publics. Therefore, it is the duty of the public relations practitioner to be able to identify who its target publics are in achieving the goal and success of the organization.

In identifying the general public of an organization as well as the problem faced by each, Ajala (2001) classify the procedure as follows:

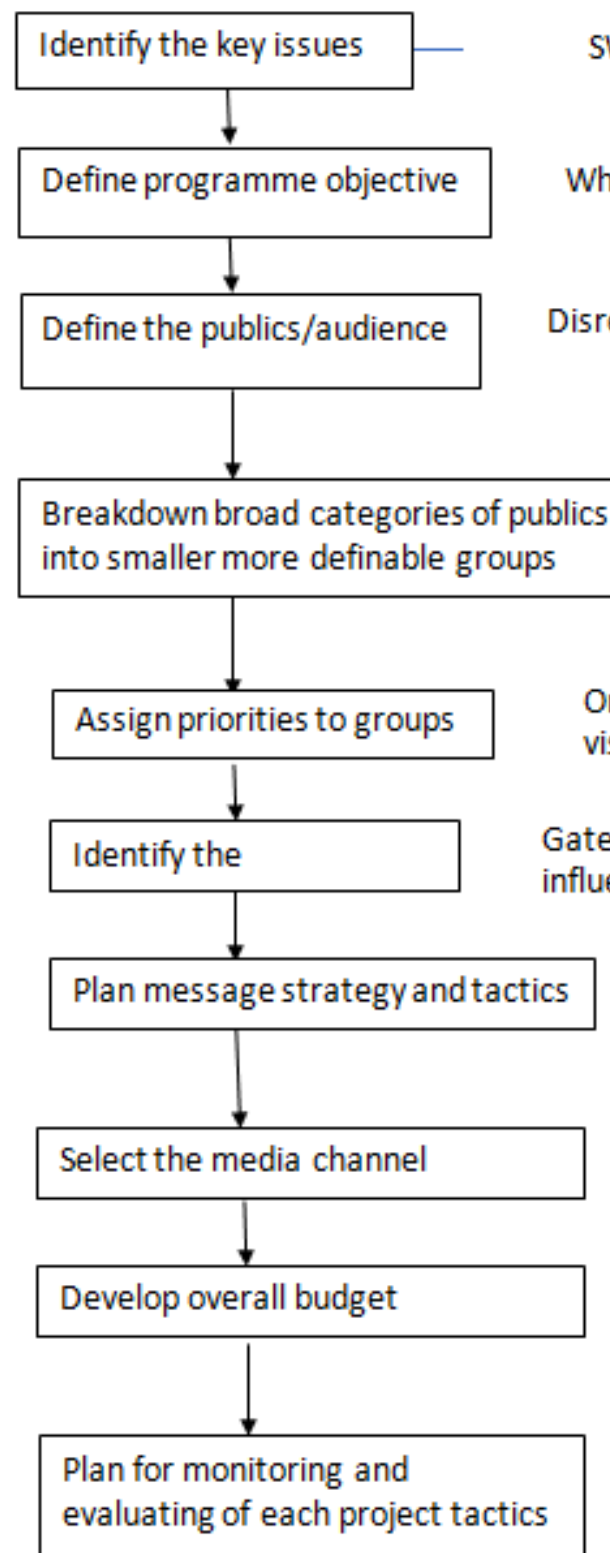

SWOT Analysis Communication

What do you want to achieve?

Disregard the idea general public

Does the organization have commercial or trading relationship with the public or are the public's internal or external publics of organization

On scale of 1 to 10 rate each public to the organization vis - a - vis the issue at hand

Gatekeeps are the opinion leaders who have strong influence on the rest of the public

Strategy is the scheme whereby a company's resource are deployed in order to surprise competitions. Tactics are the technique to implement strategy.

Channel should be those that the public use.

What will it cost to achieve objective?

Do we achieve sufficient media coverage? Did we achieve our goals? 
The last procedure is very important to every organization in achieving its goals and objectives. In a situation whereby such organization did not acquire its expected goals and objectives, it means all planning right from the very beginning, has not been effective, and as such rendering the plan abortive.

Selecting the target publics and assigning priorities to such group can be described as fishing out the most relevant among the many publics of an organization in existence at any time.

The classification as given by Moss, was further countered by Seitel (1987) when he gave overlapping categories to include; Internal Publics e.g. employees, labour unions, External Publics e.g. media, government bodies, Primary Publics: most important publics that can most help or hinder organizational growth and development, Secondary Publics: less important publics, Marginal Publics: least important publics of all, Traditional and Future: employees and existing customers are traditional publics, while students and potential customers are future ones, Proponents, Opponents and Uncommitted Publics: The publics that support an organization and those that oppose it.

Based on the classification of publics given by the two scholars above, it could be said that, there are myriads of critical publics with whom the organization must communicate daily and regularly. And unless they are carefully selected from the general publics, it then becomes difficult for the organization to know who its target publics are.

\section{Role of Public Relations in Image Building}

According to Olins (1989), "Image is the totality of all the impression that a company makes on all its audience". Every organization has an image to protect and once it is perceived wrongly by its audience (publics), such organization is bound to crumble. To Ajala (1993:168) "image contributes positively towards the success, growth, and survival of any organization". Nicholas (1992:33) says "' the most potent way to look at image is as something which affects and is affected by everything that an organization says or does". Yusuf (1993) maintained that, the corporate identity of any organization is affected either positively or negatively or by the way the public perceives or sees its corporate mission and vision as well as its corporate communication.

Image, are meant to be maintained and sustained over time, it is not a short term thing, rather a long term process. As such, the public relations executive becomes eminent as seen in the diverse roles played, who goes against all odds, insist on disseminating factual information with a view to creating perfect knowledge. More so, the PR executive does this by ensuring that the image of its organization is well perceived by its audience (publics).

The primary goal of every good public relation programme or activities, is to secure a good reputation for an organization in the face of its relevant publics. Acknowledging the importance of a good reputation to any organization, Moss
(1990) explains that, reputation is made up of everything that is known, understood, believed, rumored, thought, perceived and reported by those concerned in anyway with an organization. This goes further to justify that, every item of information, opinion aired, article published about an organization contributes to the image building of that organization. It is based on all this (service rendered), that the publics of such organization tend to perceive it either positively or negatively.

Therefore, it becomes necessary that the public relations executive watch on regular basis, the organizations corporate image and seek ways of improving it.

Public relations, is much more than just cultivating contacts, rather it is about devising and implementing strategic campaign, reacting to crisis, and ensuring the organization is always correctly and positively presented in the sight of its publics (Nwosu, 1998). Image in public relations, are formed based on information, product/service, as well as corporate organization. Akande (1999:48), who defined image as "an impression people have about an organization or place based on their knowledge and, or experience", further classified into the current image, mirror image, wish image, multiple images, ultimate image, corporate image and product/ service image.

\section{Process in Public Relations}

Organized public relations be it in business and industry, government, educational institutions, hospitals, banks, community and social affairs, does not just take place in a vacuum rather they are planned over time. This involves some laid down principles, process or procedures which have to be strictly followed such as the RACE Model, where R stands for Research, A for Action, C for Communication and $\mathrm{E}$ for Evaluation. According to Black (1989:3), "a typical public relations activities" involve analyzing research and defining problems, drawing up a programme of action and budget, communicating and implementing the programme and monitoring the result, evaluation and possible modification.

Similarly, Seitel (1987:62) says, "a typical public relations campaign plan entails back grounding the problem, programming the approach, (identifying target audience, considering research methods, selecting specific messages and appeals and considering communication vehicles), activating the plan, and evaluating the campaign

To Cutlip, Center and Broom (1985:200), it is called the four -step process" which include defining public relation problem (situation analysis), planning and programming (strategy), taking action and communication (implementation), and evaluating the programme (Assessment).

Despite all these definitions, there is a general consensus on the key elements which need to be included in any public relation plan. The planning model given by Seitel (1987), seems to be more detailed than the rest by identifying and elaborating more on the component of the public relations process. 
Research in the acronym which the letter R stands for, entails conducting a study aimed at identifying an organization's problems, and finding out the publics (both internal and external opinion and perception about the organization. According to Ajala (2001:186), research is used in public relation at the planning stage to identify the problem, refine the understanding of the problem, identify forces at work within internal and external environments, identify the relevant publics, identify the prevailing perceptions of the organization (corporate image), and analyze the relationship between the organization and the publics. The relevant questions to ask include:

a) What is the source of the organization's problems?

b) Where exactly is the problem?

c) When did the problem start?

d) Who is involve or affected by this problem?

e) How are they involved or affected?

f) Why is this a concern to the organization and its publics? (Ajala, 2001).

\section{Corporate Social Responsibility}

Corporate social responsibility came into literature in the 1980's, and since then has become a vital aspect of business public relations. It emphasizes the need for every organization to be sensitive to the needs and interests of members of the society or community in which they exist and operate as a way of eliciting and keeping their goodwill and support, (Nwosu, 1998).

According to Holme and Watts (2005:45), "corporate social responsibility is the continuing commitment by business to behave ethnically and contribute to economic development while improving the quality of lives of the work force and their families as well as of the local community and society at large". Every public of an organization tend to contribute to the success of the organization, and once their needs are not met by such organization, can lead to image crisis. Therefore, it is required of an organization, that having made a large profit from its publics, it should in return contribute to their lives in a meaningful way by focusing on those areas of their life's that affects them most.

These areas could be regarded as: Education, Economic growth, employment etc. corporate social responsibility encompasses fairness, transparency, and openness to all internal and external publics of an organization and as such be a core part for the organization's goals and activities.

\section{THEORETICAL FRAMEWORK}

A theory according to Wimmer and Dominick (1987) "is a set of related propositions that presents a systematic view of phenomena by specifying relationship among concepts". Theories are propounded on the basis of an outcome of tested hypothesis in previous research works, and must have the characteristics of universal acceptability. However, researchers develop theories by searching for patterns of uniformity to explain the data that have been collected. In other words, theoretical framework aids in distinguishing between the scientific and unscientific propositions.

According to Ngu (2005:20), "Theoretical framework is basically concerned with discussions of a certain number of existing theories derived or constructed out of results of previous research works, and which are relevant to the problem under study". Johnston and Zawawi (2004:23) postulated further, thus; "theoretical approaches provide a framework through which questions are raised and the nature of events and processes is probed and analyzed". Therefore, the relationship management theory, form the basis for this research study.

\section{The Relationship Management Theory}

This theory as propounded by Ledingham and Bruning (2000) is anchored on the management relationship with the relevant publics, in a view to creating cordial relationship. The theory is relevant to this research because it depicts the importance of a relationship management as a paradigm for public relations. It however, calls into question, the essence for public relations that is, what it is and what it does or should do, its functions and value within the organizational structure and the greater society, as well as the benefits it generates. The relationship management approach to public relations is centered on the dimensions or parameter of a relationship.

These dimensions or parameters, are aspects in the relationship between the organization sponsoring the public relations and the target of that project. However, the factors in the relationship are centered on the following:

The ability of parties to adapt in the relationship: the balance of power; whether people are trying to be constructive; whether people are been open about things; Each party's level of commitment to the relationship; How corporative each part is; the credibility of the different parties; Whether synergy is produced in the relationship; How intimate or frosty the relationship is; How much time and effort each party invests in the relationship; whether the relationship is legitimate to everyone; whether the parties have mutual goals; Whether there is some legal requirement for corporation; Whether the parties have mutual friends; The sort of satisfaction attained; Whether the use of shared resources is facilitated; Whether the party can unite to tackle a common task; whether there are existing social or organizational bonds or structure in place; whether change is advantageous or best avoided by either or some parties; Whether the parties trust each other, and whether the parties understand each other and each other's needs.

Given the above factors involved in the relationship, it is important to note that the role of public relations in creating cordial relationship with relevant publics is centered on the aforementioned factors. Most organizations do not identify with the publics the kind of relationship it is into, while others (organizations) tend to neglect the fact and importance of engaging in any relationship with its publics. This is what MTN Nigeria, being an organization helps in illustrating 
through its social investment (MTN Foundation connect), by focusing on three key areas (Education, Health, and Economic empowerment) in meeting the needs as well as creating a cordial relationship with its relevant publics. But how effective and cordial is the relationship buttressed by MTN especially in the area of Education (Universities Connect), as the study is set to research on.

In addition, the purpose of the relationship management approach, is to encourage organizations, as well as PR practitioners to break down the relationship concern with public relations into its component parts, in order to measure each part. A proper understanding of each aspect of the relationship enables one to make more satisfactory inference about what sort of relationship is being dealt with and a better analysis of how that relationship changes as a result of public relations programme.

The relationship management approach therefore buttresses the fact that, MTN Foundation, as a corporate social responsibility, must identify with the factors, in the relationship with relevant publics as stated in the theory, in an attempt to achieve a mutual goal.

\section{METHODOLOGY}

The survey research design was used for the study. Survey is adopted because it focuses on population which aids the researcher to collect large amount of data with relative ease from a variety of people. Questionnaire was used to elicit data from the respondents.

\section{Data Analysis and Presentation}

Data was presented and analyzed using the descriptive method as well as simple percentage in tabular forms, frequency count, and statistical analysis.

\section{Demographic Data}

Table 1: Frequency Distribution of Respondents Age

\begin{tabular}{|c|c|c|}
\hline Age Class & Frequency & \\
\hline & $\mathbf{n}$ & $\boldsymbol{\%}$ \\
\hline $21-25$ & 9 & 7.5 \\
\hline $26-30$ & 67 & 55.8 \\
\hline 31 and above & 38 & 31.7 \\
\hline Total & 6 & 5.0 \\
\hline
\end{tabular}

Source: Field Survey 2008

The table above shows that majority of the respondent are within the age of 21- 25 forming the bulk of the sample.

Table 2: Frequency Distribution of Respondents sex

\begin{tabular}{|c|c|c|}
\hline Sex & & Frequency \\
\hline & n & \% \\
\hline Male & 93 & 77.5 \\
\hline
\end{tabular}

\begin{tabular}{|c|c|c|}
\hline Female & 27 & 22.5 \\
\hline Total & $\mathbf{1 2 0}$ & $\mathbf{1 0 0}$ \\
\hline
\end{tabular}

Source: Field Survey 2008

From the table above, it can be deduced that male respondents are more than female respondents.

Table 3: levels of Respondents

\begin{tabular}{|c|c|c|}
\hline Students Levels & Frequency & \\
\hline & $\mathbf{n}$ & $\boldsymbol{\%}$ \\
\hline 100 & 5 & 4.2 \\
\hline 200 & 21 & 17.5 \\
\hline 300 & 32 & 26.7 \\
\hline 400 & 39 & 32.5 \\
\hline 500 & 17 & 14.2 \\
\hline 600 & 6 & 5.0 \\
\hline Total & $\mathbf{1 2 0}$ & $\mathbf{1 0 0}$ \\
\hline
\end{tabular}

Source: Field Survey 2008

The above content shows that, a larger percentage of the respondents constituting $32.5 \%$ are from $400 \mathrm{~L}$, meaning those in this level, responded to question more than those in other levels.

Table 4: Computer Literacy Level of Respondents

\begin{tabular}{|c|c|c|}
\hline $\begin{array}{c}\text { Whether or not Respondents are Computer } \\
\text { Literacy }\end{array}$ & Frequency & \\
\hline & $\mathbf{n}$ & $\boldsymbol{\%}$ \\
\hline Yes & 112 & 93.3 \\
\hline No & 8 & 6.7 \\
\hline Total & $\mathbf{1 2 0}$ & $\mathbf{1 0 0}$ \\
\hline
\end{tabular}

Source: Field Survey 2008

Majority of the respondent are computer literate, while only eight (8) are not

\section{SECTION B}

\subsection{Awareness}

Table 5: Awareness of the A.B.U./MTN Library Connect Service

\begin{tabular}{|c|c|c|}
\hline $\begin{array}{c}\text { Whether or not Respondents are aware Of } \\
\text { the MTN Library Connect Service }\end{array}$ & Frequency & \\
\hline & $\mathbf{n}$ & $\boldsymbol{\%}$ \\
\hline Yes & 120 & 100 \\
\hline No & 8 & 0 \\
\hline Total & $\mathbf{1 2 0}$ & $\mathbf{1 0 0}$ \\
\hline
\end{tabular}

Source: Field Survey 2008

Data in table 5 show that all the respondents are aware of the A.B.U./MTN Library Connect Service. 
International Journal of Research and Innovation in Social Science (IJRISS) |Volume V, Issue XI, November 2021||ISSN 2454-6186

Table 6: Did You Undergo any Training by the A.B.U/MTN Connect Library

\begin{tabular}{|c|c|c|}
\hline Trained & Frequency & \\
\hline & $\mathbf{n}$ & $\mathbf{\%}$ \\
\hline Yes & 26 & 21.7 \\
\hline No & 94 & 78.3 \\
\hline Total & $\mathbf{1 2 0}$ & $\mathbf{1 0 0}$ \\
\hline
\end{tabular}

\begin{tabular}{|c|c|c|}
\hline Disagree & 31 & 25.8 \\
\hline Neutral & 18 & 15.0 \\
\hline Total & $\mathbf{1 2 0}$ & $\mathbf{1 0 0}$ \\
\hline
\end{tabular}

Source: Field Survey 2008

Majority of the respondents agreed that the MTN Library Connect has helped in solving their research needs, constituting $34.2 \%$, while a total of 18 were neutral.

Table 10: Whether or not MTN Library Connect has helped in Creating the required understanding and easy Accessibility to its Facilities

The analysis shows that majority of the respondents did no undergo any training by the ABU/MTN Connect Library

Table 7: Rating of the Training

\begin{tabular}{|c|c|c|}
\hline Ratings & Frequency & \\
\hline & $\mathbf{n}$ & $\mathbf{\%}$ \\
\hline Very helpful & 15 & 57.7 \\
\hline Somewhat helpful & 6 & 23.1 \\
\hline Not helpful & 2 & 7.7 \\
\hline Neutral & 3 & 11.5 \\
\hline Total & $\mathbf{2 6}$ & $\mathbf{1 0 0}$ \\
\hline
\end{tabular}

Source: Field Survey 2008

From the two tables above of which table 7 is a follow-up question to table 6 , one can infer that majority of the respondent did not undergo the training. While on the rating of the training, majority of those that undergo the training, said it was very useful constituting $57.5 \%$

\subsection{Effectiveness}

Table 8: Reliability of MTN Connect Library Service.

\begin{tabular}{|c|c|c|}
\hline Levels of Agreement & Frequency & \\
\hline & $\mathbf{n}$ & $\mathbf{\%}$ \\
\hline Strongly Agree & 13 & 11.0 \\
\hline Agree & 57 & 47.9 \\
\hline Strongly Disagree & 14 & 11.8 \\
\hline Disagree & 19 & 15.9 \\
\hline Neutral & 119 & 13.4 \\
\hline Total & $\mathbf{1 1 9}$ & $\mathbf{1 0 0}$ \\
\hline
\end{tabular}

Source: Field Survey 2008

The result reveals that majority of the respondent were of the view that MTN connect Library has always provided reliable service since its inception, one out of the respondent did not attempt the question.

Table 9: Views on the ability of the MTN Connect Library in solving Research needs

\begin{tabular}{|c|c|c|}
\hline Responses & Frequency & \\
\hline & $\mathbf{n}$ & $\boldsymbol{\%}$ \\
\hline Strongly Agree & 12 & 10.0 \\
\hline Agree & 41 & 34.2 \\
\hline Strongly Disagree & 18 & 15.0 \\
\hline
\end{tabular}

\begin{tabular}{|c|c|c|}
\hline Responses & Frequency & \\
\hline & $\mathbf{n}$ & $\mathbf{\%}$ \\
\hline Strongly Agree & 12 & 10.0 \\
\hline Agree & 44 & 36.7 \\
\hline Strongly Disagree & 13 & 10.8 \\
\hline Disagree & 35 & 29.2 \\
\hline Neutral & 16 & 13.3 \\
\hline Total & $\mathbf{1 2 0}$ & $\mathbf{1 0 0}$ \\
\hline
\end{tabular}

Source: Field Survey 2008

From the above table, majority of the respondents agreed that the MTN Library Connect has helped in creating the required understanding and easy accessibility to its facilities. 10.8\% strongly disagreed, while $13.3 \%$ were neutral.

Table 11: Describing the service of MTN Library Connect

\begin{tabular}{|c|c|c|}
\hline Responses & Frequency & \\
\hline & $\mathbf{n}$ & $\mathbf{\%}$ \\
\hline excellent & 1 & 0.8 \\
\hline Very Good & 11 & 9.2 \\
\hline Good & 50 & 41.6 \\
\hline Fair & 41 & 34.2 \\
\hline Poor & 17 & 14.2 \\
\hline Total & $\mathbf{1 2 0}$ & $\mathbf{1 0 0}$ \\
\hline
\end{tabular}

Source: Field Survey 2008

As seen in the table above, only 1 out of the respondents describes the service as excellent, while 50 constituting $41.6 \%$ describe it is good, forming the bulk of the sample.

Table 12: Ratings of Staff/Students Relationship of the A.B.U/ MTN Library Connect

\begin{tabular}{|c|c|c|}
\hline Responses & Frequency & \\
\hline & $\mathbf{n}$ & $\mathbf{\%}$ \\
\hline cordial & 25 & 21.0 \\
\hline Somewhat Cordial & 52 & 43.3 \\
\hline Not Cordial & 28 & 23.3 \\
\hline No Response & 15 & 12.5 \\
\hline Total & $\mathbf{1 2 0}$ & $\mathbf{1 0 0}$ \\
\hline
\end{tabular}

Source: Field Survey 2008 
The table shows that the relationship of Students/Staff of the A.B.U/MTN Library Connect is somewhat cordial. As seen in the percentage $(43.3 \%)$ of those who says it is somewhat cordial constituting the highest figure.

\section{General Comments on How the MTN Library can be Improved Upon}

When the respondents were asked to comment freely on how they think the MTN Library Connect can be improved upon, the comments made include:

1) There should be provision of more servers for easy accessibility/connectivity

2) More time should be allocated to students for browsing.

3) The areas should be extended so as to accommodate more students.

4) By training students effectively on the use of the library connect.

5) They should employ more staffs that would help in solving user's problems and needs.

6) More search engines should be incorporated alongside Google.

7) Their services are good but need to be improved.

\section{DISCUSSION OF FINDINGS}

The findings on awareness in terms of training shows that, majority of the respondents were not trained on the use of the library constituting $78.3 \%$. while out of the 26 that were trained, $57.7 \%$ rated the training as very helpful. This Implies that, a larger percentage out of those who were trained on the use of the library connect, benefited a lot from the training.

Findings on effectiveness of the MTN Library Connect service reveals that the connect has been effective in the areas of providing reliable service, solving students research needs and creating the required understanding and easy accessibility to its facilities. As seen in tables 8,9 , and 10 constituting a larger percentage of those who said they agreed. Furthermore, research question on table 2 described the MTN Library Connect service has been good (average). This implies that the library connect is performing satisfactorily. Thus, this is justified based on the table, seen in the responses given whereby a higher number of 50 out of the entire respondents described the service as good.

More so, findings in table 12 about the staff/students' relationship of the A.B.U./MTN Library Connect says the relationship is cordial. One can further deduce from this that, staff of the MTN Library Connect has helped in building, as well as maintaining cordial relationship over time.

According to the findings of Mallo Daniel Uhwet Titled: Trade fare as a public relations technique, a case study of Peugot Automobile Nigeria (PAN). It was discovered that PEUGOT has gained a large publicity, based on the fact that it owes largely to trade fare. The company does these by investing largely in their stand creation so that they eventually grasp visitor's attention, and subsequently change their perception about them to a more positive one.

The findings, further reveals that, the company (PEUGOT) invests is its image creation by training experts in public relations and automobile technology to man their stands and deliver lectures. Linking this with MTN Foundation Connect reveals that MTN Foundation Connect invest in Education by Impacting on the Life's of students of higher learning through digitalized Universities Connect Libraries. This is justified based on the findings of the A.B.U/MTN Library connect, which further reveals their level of commitment to the project.

Finally, people perceive an organization either positively or negatively, based on the level of commitment, satisfaction, and cordial relationship that organization is into, or has maintained over time with its public. Thus, all this the relationship management theory postulates. However, one could see from the findings that MTN Foundation Connect, through the A.B.U/MTN Library Connect has to some extent, maintain a level of commitment in its relationship with the public (Students).

\section{CONCLUSION AND RECOMMENDATIONS}

The paper examined the role of public relations in creating cordial relationship with the relevant publics, of MTN Library Connect in Ahmadu Bello University, Zaria. It further states some research problems as found with most organizations, who tend to give little or nothing in return to the society in which they operate, after gaining a lot of profit from them.

Thus, this was stated in line with MTN Nigeria, investing massively in corporate social responsibility through its project (MTN Foundation Connect) as seen in institution of higher learning in Nigeria. To determine if in really it is committed to giving back to the society. The analysis of result shows that:

1) Majority of the students were not trained on the use of the library connect

2) A larger percentage of those who were trained rated the training as very helpful.

3) The A.B.U/MTN Library Connect has been effective in the areas of providing reliable service, solving research needs, and creating the required understanding and easy accessibility to its facilities.

4) The library connect is performing satisfactorily despite the challenges.

5) There is a cordial relationship that exists between students and staff of the library connect.

\section{Conclusion}

Based on the findings, the following conclusion is reached. It is obvious that majority of the students appreciate the services rendered by the A.B.U/MTN Library Connect. The MTN Library Connect is seen to be effective in carrying out its social responsibilities of creating cordial relationship as well as providing students with the necessary facilities in carrying out their research. In addition, the success of any organization 
depends upon the cordial relationship it has with its various publics.

\section{Recommendations}

Based on the conclusion, the following recommendations are made:

1) MTN Management should intensify efforts in creating more awareness, in training students/users on the use of the library connect.

2) Since quite a number of students appreciate the services, the area should be extended so as to accommodate more students.

3) Also, more systems should be provided, as well as servers in order to aid easy connectivity.

4) More staff should be employed by the MTN Management so as to improve more on their effectiveness and maintain a better relationship.

5) More search engines should be installed in the systems to provide alternatives for the students/users.

\section{REFERENCES}

[1] Ajala, V. (2005), Public Relations: in Search of Professional Excellence, Revised Edition, Ibadan: Africa Link Publishers.

[2] Akande, F. (1999, 2001), . Principles and Techniques of Public Relations, Lagos: Fest Communications.

[3] Black, S. (1990). Introduction of Public relations London: Modino Press.

[4] Cutlip, M., and Broom, M. (1985). Effective Public relations, $6^{\text {th }}$ Ed. New Jersey: Patience Hall Inc.

[5] Daramola, I. (2003). Introduction to Mass Communication, $2^{\text {nd }}$ Ed. Lagos: Rothan Ltd.

[6] Haywood, R. (1984). All About Public Relations. Britain: McGraw-Hill Book Company Ltd.

[7] Holme, L. and Watt, R. (2005). Making Good Business Sense. London: Englewood Cliffs.

[8] Johston, E., and Zawawi, M. (2004). Public Relations; Theory and Practice. Australia: Allen and Unwin Publishers.

[9] James, E. et al. (2004). Managing Public Relations, Orlando: Harcourt Brace Publishers.

[10] Lesly, P. (1991). Public Relations Handbook, $2^{\text {nd }}$ Ed. New York: Prentice-Hall Inc.

[11] MTN Foundation. (2006). Improving the quality of Life in Our Communities.

[12] Ngu, S. M. (2005). Research Methodology: Made Simple for Social and Behavioural Science. Kaduna: Shereef Salam Press.

[13] Nichols, I. (1992). The Corporate Image Strategies for effective Identity Programmes. London: Kogan Page Ltd.

[14] Nwosum I. (1998). Public Relations Management. Port Harcourt: Domician Publisher.

[15] Oxley, H. (1987). Principles of Public Relations. London: Kogan Press Ltd.

[16] Peil, S. (1982). Social Science Research Method. Londan: Hodder and Stronghen Publishers.

[17] Seitel, F. (1987). The Practice of Public Relation, $3^{\text {rd }}$ Ed. Columbus: Ohio, Merrill publishing Company.

[18] Wilcox, D. et al. (1998). Public Relations Strategies and Tactics, $3^{\text {rd }}$ Ed. New York: Hereer Collins Publishers.

[19] Wimmer, R. D. and Dominick, J. R. (1987). Mass Media Research; An Introduction, 2nd Ed. California: Wadsworth.

[20] Yusuf, F. A. (1993). Public Relations as a Management Function. Lagos Talkback Publishers. 